Durham Observatory at $11 \mathrm{~h} .37 \mathrm{~m} .59 \mathrm{~s}$. and $1 \mathrm{lh}$. $38 \mathrm{~m}$. 38s., G.M.T. On March 29 one of the earthquakes of magnitude $7 \frac{1}{4}$ occurred in the Sierra Nevada in the south of Spain. Extensive minor property damage occurred over a very wide area, but the maximum felt intensity was only about 4 on the Modified Mercalli scale. The shock was recorded at Edinburgh at 06h. $21 \mathrm{~m}$. 04s., G.M.T., and over a very wide area. More than a hundred observatories sent seismogram readings to Strasbourg, where the initial time of the earthquake was evaluated as at 16h. $17 \mathrm{~m} .09 \mathrm{~s}$., G.M.T., and the epicentre at lat. $37^{\circ}$ N., long. $3 \frac{1}{4}^{\circ} \mathrm{W}$. From the facts already mentioned, from arrival times at the various observatories, and from the observations that surface waves, if present, had extremely small amplitudes, it is considered that this earthquake had a very great depth of focus $(600-650 \mathrm{~km}$.). This is most unusual, since earthquakes with such great depths of focus have only previously been known from foci near the Pacific Ocean; none has previously been found in Europe since adequate instrumental recording began (say fifty years ago). The other shocks with magnitude 71 occurred on March 3 with an epicentre in Central New Guinea and on March 31 with an epicentre in the Arabian Sea; the only other shock with deep focus $(550 \mathrm{~km}$.) occurred in the Fiji Island region on March 6. Apart from the above, five of the thirty-four earthquakes were experienced in Europe.

\section{Peaceful Uses of Atomic Energy}

More than seven hundred scientists, working on the peaceful uses of atomic energy in thirty different countries, are to meet at Oxford during July 19-22 to discuss advances made in the past three years. They are to attend a conference organized by the Atomic Energy Research Establishment, Harwell, on isotope techniques. Developments in medical research and treatment, in industrial processes and in agricultural research will be discussed. Britain has become the leading exporter of isotopes to Europe, the Commonwealth and other countries outside the United States. Most of the materials come from Harwell; but at the Radiochemical Centre, Amersham, the work of a team of chemists specializing in the production of chemical compounds incorporating isotopes has been arousing world-wide interest. Orders at these two centres are now being dealt with at the rate of 15,000 a year, of which more than $\tilde{5}, 000$ are to other countries. In the past six years radioactive isotopes have been sent to forty-two different countries from the United Kingdom. The conference will be opened by Sir John Cockeroft, director of the Atomic Energy Research Establishment, Harwell. The sessions will be private, but further information can be obtained from the Secretary, Atomic Energy Research Establishment, Harwell, Nr. Didcot.

\section{Royal Meteorological Society: Officers for 1954-55}

THE following have been elected officers of the Royal Meteorological Society for the year 1954-55: President, Dr. O. G. Sutton; Vice-Presidents, Prof. P. R. Crowe, Sir Charles Normand, C. D. Ovey and Prof. P. A. Sheppard; Vice-President for Canada, F. W. Benum; Vice-President for Scotland, Dr. A. E. M. Geddes ; Treasurer, Dr. J. S. Farquharson; Secretaries, Dr. H. L. Penman, Dr. G. D. Robinson (librarian), R. G. Veryard and Dr. T. W. Wormell (editor).

\section{Announcements}

THE following elections have been made in the Paris Academy of Sciences: M. André Couder, director of the Paris Section of the Service des Mouvements Progrès Stellaires, to be a member of the Astronomy Section, in succession to the late Prof. E. Esclangon; Prof. J. Kampé de Feriet, professor of fluid mechanics in the University of Lille, to be a correspondant for the Mechanics Section in succession to Prof. I. Escande, recently elected a non-resident member of the Section.

MR. R. D. EDGE, of the Cavendish Laboratory, Cambridge, has been appointed a Research Fellow in the School of Physical Sciences of the Australian National University, Canberra. $\mathrm{He}$ will work with Prof. E. W. Titterton on the $30-\mathrm{MeV}$. electron synchrotron which will shortly be erected in the Department of Nuclear Physics. This machine, which was in use at the Atomic Energy Research Establishment, Harwell, until recently, was given by the U.K. Government to the Australian Government for installation in Canberra.

Dr. Charles Kemball, demonstrator in physical chemistry in the University of Cambridge, has been appointed to the chair of physical and inorganic chemistry in The Queen's University of Belfast. The following have been made lecturers in the University : V. C. R. Ford (geography), J. Drewery (psychology), Dr. W. Schwarzacher (geology).

THE thirty-third annual general meeting of Fellows of the National Institute of Agricultural Botany will be held at Cambridge on July 16 ; Sir John Russell is to address the meeting.

Tнe Universities Federation for Animal Welfare will be holding a summer school, open to both members and non-members of the Association, at Knuston Hall, Northamptonshire, during September 18-25. The programme will include expeditions to the Animal Health Trust Research Station at Huntingdon and to an artificial insemination centre and to Cambridge, as well as lectures, discussions and social activities. A fee of 5 guineas, which will include full board and all the expeditions, will be charged ( 3 guineas for students). Application and all other communications should be sent to the local branch secretary of the Association or to Miss M. Williams, UFAW, $7 a$ Lamb's Conduit Passage, London, W.C.1.

THE Electrical Engineering Department of the Imperial College of Science and Technology, London, will hold a five-day vacation school on aireraft electrical systems during September 20-24. The course is designed for a maximum of sixty engineers who already have some experience in the design and application of aircraft electrical power equipment, the object being to bring out, partly by lectures and partly by mutual discussion, the scientific principles underlying the design and application of all types of equipment. The fee for the course (including lunches, refreshments, transport, etc.) will be eight guineas. Hostel accommodation is available. Further information can be obtained from B. Adkins, Department of Electrical Engineering, Imperial College of Science and Technology, London, S.W.10. 